\title{
Slaughter condemnation in bovine due to parasitic lesions and their economic impact in Federal Inspection System establishments in Brazil and in State inspection System in Rio Grande do Sul State
}

\author{
Condenação ao abate em bovinos devido a lesões parasitárias e seu impacto \\ econômico em estabelecimentos do Sistema Federal de Inspeção no Brasil e \\ no Sistema Estadual de Inspeção no Rio Grande do Sul \\ Nathalia de Bem Bidone ${ }^{1,2}$ (1); Ana Paula Gonçalves ${ }^{1}$ (D); Carolina Bremm² (D); Ademir Francisco Girotto3; \\ Aline Girotto-Soares ${ }^{4}$ (D); Paulo Santos²; Andrea Troller Pinto ${ }^{1}$ (D); João Fabio Soares ${ }^{1 *}$ (D) \\ ${ }^{1}$ Faculdade de Medicina Veterinária - FAVET, Universidade Federal do Rio Grande do Sul - UFRGS, Porto Alegre, RS, Brasil \\ ${ }^{2}$ Secretaria da Agricultura Pecuária e Irrigação - SEAPI/RS, Porto Alegre, RS, Brasil \\ ${ }^{3}$ Pesquisador da Área de Economia, Embrapa Suínos e Aves, Concórdia, SC, Brasil \\ ${ }^{4}$ Instituto de Pesquisas Veterinárias Desidério Finamor - IPVDF, Eldorado do Sul, RS, Brasil
}

How to cite: Bidone NB, Gonçalves AP, Bremm C, Girotto AF, Girotto-Soares A, Santos P, et al. Slaughter condemnation in bovine due to parasitic lesions and their economic impact in Federal Inspection System establishments in Brazil and in State inspection System in Rio Grande do Sul State. Braz J Vet Parasitol 2021; 30(1): e022720. https://doi.org/10.1590/S1984-296120201079

\begin{abstract}
Slaughter condemnations are important sources of information on cattle health. The incidence of bovine parasitic diseases is still very high in Brazil. These diseases, in addition to causing harm to the animals health, are neglected zoonotic diseases in several parts of world. The study analysed not only the Carcass losses, but also the economic damage resulting from slaughter condemnations due to parasitic causes. Cattle slaughter data from the Brazilian Ministry of Agriculture, Livestock and Supply (MAPA), over the period of 2012 to 2015 and data from the Secretary of Livestock and Irrigation of the state of Rio Grande do Sul (SEAPI-RS) were analyzed between 2014 and 2018. The number of organs and carcasses condemned was multiplied by the respective values (in Brazilian Real) obtained from slaughterhouses and subsequently converted into dollars. Brazilian analysis in SIF (Federal Inspection System) establishments showed that more than 1.2 million organs (3,884,505 kg) and 20,000 carcasses (4,547,718 kg) were condemned only due to parasitic causes during post-mortem inspection. In Rio Grande do Sul, in state inspection establishments, more than 1.7 million organs $(8,210,559 \mathrm{~kg})$ and 5,000 carcasses $(1,243,200 \mathrm{~kg})$ were condemned. These data are alarming and support the need for public policies to control these parasitic diseases.
\end{abstract}

Keywords: Parasitic diseases, economic losses, cattle slaughter, inspection service.

\begin{abstract}
Resumo
Condenações durante o abate são importantes fontes de informação sobre a sanidade dos rebanhos. Ainda são altas as incidências de doenças parasitárias, as quais trazem consequências à saúde dos animais, são zoonoses e têm sua importância negligenciada em diversos países. O estudo objetivou quantificar não apenas as perdas encontradas, mas o prejuízo econômico resultante das condenações ao abate por causas parasitárias. Para isso foram analisados dados de abate de bovinos do Ministério da Agricultura Pecuária e Abastecimento, no período de 2012 a 2015, e dados da Secretaria da Agricultura Pecuária e Irrigação, do estado do Rio Grande do Sul, no período de 2014 a 2018. A quantidade de órgãos e carcaças condenados foi multiplicada pelos respectivos valores (em Reais), obtidos da indústria frigorífica e, posteriormente, convertidos para dólar. A análise brasileira de estabelecimentos com SIF (Serviço de Inspeção Federal) mostrou que mais de 1,2 milhão de órgãos (3.884.505 kg) e 20 mil carcaças $(4.547 .718$ kg) foram condenados devido a causas parasitárias durante a inspeção. No estado do Rio Grande do Sul, nos estabelecimentos de inspeção estadual, foram condenados mais de 1,7 milhão de órgãos (8.210.559 kg) e 5 mil carcaças (1.243.200 kg). Os dados são alarmantes e ressaltam a necessidade de políticas públicas para controlar estas parasitoses.
\end{abstract}

Palavras-chave: Doenças parasitárias, perdas econômicas, abate bovino, serviço de inspeção. 


\section{Introduction}

Brazil, with its 226 million cattle population, has $22.6 \%$ of the total cattle worldwide. Brazilian beef production is the second largest in the world, with the United States ranking first for meat production (FAO, 2016). Products resulting from the process of slaughtering bovine are called carcasses and by-products; organs are economically important, because they add value to production and are potential sources of nutrients, especially with the increasing world population size and the increasing demand for high quality protein (Kale et al., 2008).

In addition to causing decreased performance of animals in vivo, parasitic diseases such as cysticercosis, fasciolosis and hydatidosis cause carcass and organ damage due to the stages of parasite's biological cycle. These injuries, when identified at slaughter, result in elimination of the carcass or part of the carcass or organ as it cannot go to human consumption, generating an economic loss.

Nosographic data obtained from slaughterhouses are an important source of information, and economic losses due to condemnations of affected organs and carcasses can be estimated through them (Nif \& Alonge, 1987). There are three inspection systems to animal by-products in Brazil, federal, state and municipal and they are not interconnected, each one has a different database. The main reasons for condemnations in cattle slaughterhouses are due to lesions associated with cysticercosis (Marques et al., 2008; Dutra et al., 2012), hydatidosis (Cabrera et al., 2002, Tessele et al., 2013) and fasciolosis (Dutra et al., 2010); all of these are parasitic and zoonotic diseases, which are often neglected in the prevention aspect (Molento \& Pritsch, 2018). Economic research of animal health aims to quantify the financial effects of diseases so that methods can be developed to optimize decisions when animal populations are affected and determine the costs and benefits of disease control (Dijkhuizen \& Morris, 1997).

In the face of a large number of studies demonstrating the occurrence of condemnation due to parasitic diseases and knowing that the data are generally restricted to the sanitary and industrial inspection of animal products, the objective of this analysis was to characterize the economic loss due to parasitic lesions of bovines in SIF (Federal Inspection System) slaughterhouses in Brazil and also for the state of Rio Grande do Sul - RS analysing DIPOA (Animal Products Inspection Division) establishments because it has historical problems with livestock parasites and there is no consistent data to support public policies.

\section{Methodology}

\section{Data origin}

Data on numbers of animals slaughtered and their condemnations were obtained from the slaughtering information system for cattle linked to the Federal Inspection Service (SIF), from the Ministry of Agriculture, Livestock, and Supply (MAPA) available in the website from the period of 2012 to 2015. Amapá, Alagoas, Ceará, Federal District, Pernambuco, Piauí, Rio de Janeiro, Rio Grande do Norte and Roraima states were not included in the survey since only animals slaughtered under Federal inspection were considered, and in these States, there were no SIF establishment assets during the period studied.

Information regarding slaughtering in the state inspection service was collected from the slaughtering data of Rio Grande do Sul Secretary of Livestock and Irrigation (SEAPI-RS), available through direct consultation with DIPOA (data extracted from the secretariat's internal system), from when data started to be registered, 2014 to 2018. This study has been approved by the Institutional Research Committee "Comissão de Pesquisa Veterinária" (Compesq- FAVET -UFRGS) of the Faculty of Veterinary of the Federal University of the state of Rio Grande do Sul (protocol 35862).

\section{Data organization}

All the obtained data were tabulated in spreadsheets. From these, only data of interest, that is, condemnations caused by identifiable parasites in carcasses and organs that appear in the system as fasciolosis, hydatidosis, esophagostomosis and/or cysticercosis and the respective organs where these lesions were located, were filtered. To support data visualization, a spatial analysis was performed using QGIS 2.18.27 'Las Palmas' program (QGIS Trademark, 2018). 


\section{Trade data}

Values used for organ and carcass prices were provided by the meat industry, through a survey of sale prices from four slaughterhouses with an average being made. The affected parts considered in the study were those that were used commercially. The parts that presented some parasitic injury and that were not totally discarded were not counted, because they were not registered. For carcasses, the value was changed for each year studied, according to commercial variations in price.

The loss was calculated by the sales price of the injury-free part minus the sales value of the affected organ after discard to grease or conditional treatment by cold, respecting the different values involved in the different destinations (greasing or cold treatment) according to Tables 1 and 2.

Table 1. Value per unit, in Brazilian Real $(R \$)$, of the affected parts used for calculating the losses in bovine meat by-products.

\begin{tabular}{cccccc}
\hline Affected part & $\begin{array}{c}\text { Comercial value } \\
\text { (A) }\end{array}$ & $\begin{array}{c}\text { Grease value } \\
\text { (B) }\end{array}$ & $\begin{array}{c}\text { Value used for } \\
\text { calculation (A-B) }\end{array}$ & $\begin{array}{c}\text { Cold treatment } \\
\text { value (C) }\end{array}$ & $\begin{array}{c}\text { Value used for } \\
\text { calculation (A-C) }\end{array}$ \\
\hline Heart & 4.67 & 0.31 & $\mathbf{4 . 3 6}$ & 2.80 & $\mathbf{1 . 8 7}$ \\
Liver & 6.63 & 0.31 & $\mathbf{6 . 3 2}$ & 3.98 & $\mathbf{2 . 6 5}$ \\
Lungs & 0.80 & 0.31 & $\mathbf{0 . 4 9}$ & 0.48 & $\mathbf{0 . 3 2}$ \\
Kidneys & 3.80 & 0.31 & $\mathbf{3 . 4 9}$ & 2.28 & $\mathbf{1 . 5 2}$ \\
Tongue & 7.60 & 0.31 & $\mathbf{7 . 2 9}$ & 4.56 & $\mathbf{3 . 0 4}$ \\
Intestine & 4.83 & 0.31 & $\mathbf{4 . 5 2}$ & 2.90 & $\mathbf{1 . 9 3}$ \\
Stomach and & 9.17 & 0.31 & $\mathbf{8 . 8 6}$ & 5.50 & $\mathbf{3 . 6 7}$ \\
Pre-stomach & & & & & \\
Diaphragm & 10.75 & 0.31 & $\mathbf{1 0 . 4 4}$ & 6.45 & $\mathbf{4 . 3 0}$ \\
Esophagus & 2.00 & 0.31 & $\mathbf{1 . 6 9}$ & 1.20 & $\mathbf{0 . 8}$ \\
Head (muscle) & 5.30 & 0.31 & $\mathbf{4 . 9 9}$ & 3.18 & $\mathbf{2 . 1 2}$ \\
\hline
\end{tabular}

Table 2. Value, in Brazilian Real ( $R \$)$, used for calculating the losses in bovine carcasses (kg).

\begin{tabular}{cccccc}
\hline Year & $\begin{array}{c}\text { Average carcass } \\
\text { price (A) }\end{array}$ & $\begin{array}{c}\text { Grease value } \\
\text { (B) }\end{array}$ & $\begin{array}{c}\text { Value for } \\
\text { calculation (A-B) }\end{array}$ & $\begin{array}{c}\text { Cold treatment } \\
\text { value (C) }\end{array}$ & $\begin{array}{c}\text { Value for } \\
\text { calculation (A-C) }\end{array}$ \\
\hline 2012 & 8.20 & 0.31 & $\mathbf{7 . 8 9}$ & 4.92 & $\mathbf{3 . 2 8}$ \\
2013 & 8.50 & 0.31 & $\mathbf{8 . 1 9}$ & 5.10 & $\mathbf{3 . 4 0}$ \\
2014 & 10.30 & 0.31 & $\mathbf{9 . 9 9}$ & 6.18 & $\mathbf{4 . 1 2}$ \\
2015 & 12.00 & 0.31 & $\mathbf{1 1 . 6 9}$ & 7.20 & $\mathbf{4 . 8 0}$ \\
2016 & 12.80 & 0.31 & $\mathbf{1 2 . 4 9}$ & 7.68 & $\mathbf{5 . 1 2}$ \\
2017 & 13.20 & 0.31 & $\mathbf{1 2 . 8 9}$ & 7.92 & $\mathbf{5 . 2 8}$ \\
2018 & 13.20 & 0.31 & $\mathbf{1 2 . 8 9}$ & 7.92 & $\mathbf{5 . 2 8}$ \\
\hline
\end{tabular}

Price reduction of affected parts was multiplied by the total weight (kilograms-kg) of each organ or carcass sent to grease or to conditional treatment by cold (Table 3), and then converted to the dollar value of the corresponding year, thus generating the value. Calculations of dollar values were done by the annual average using the data from the site "investing" (Investing.com, 2019) which provides information for the daily currency for every year. An injury simulation was also elaborated considering all the spheres of inspection (federal, state and municipal). Considering that $77 \%$ of the cattle in Brazil are slaughtered under a Federal Inspection System (SIF), the remaining (state and municipal slaughtering) comprise $23 \%$ of slaughtering houses. Thus, we considered the possibility that the number of injuries followed the same pattern regardless the type of slaughtering house, to estimate losses for the whole country (Table 4). For the state of Rio Grande do Sul, the simulation was similar and we took into account that $49 \%$ of slaughtering occurs at establishments under the State Inspection System, 39\% under the Federal Inspection system, and $12 \%$ under the Municipal Inspection Systems. For the simulated values presented in Table 5, the values of $39 \%$ and $12 \%$ for the other inspection spheres were added. 
Table 3. Number of affected parts of bovine by parasitic causes evaluated at slaughter houses by the Federal Inspection establishments (SIF) and in the state of Rio Grande do Sul by the State Inspection Establishments - DIPOA (Animal Products Inspection Division).

\begin{tabular}{|c|c|c|c|}
\hline Affected part & Inspection sphere* & Quantity (unit) & Quantity(kg) \\
\hline \multirow[t]{2}{*}{ Head (muscle) } & Federal (SIF) & 62,792 & 163,259 \\
\hline & State/DIPOA & 17,582 & 45,713 \\
\hline \multirow[t]{2}{*}{ Carcass } & Federal (SIF) & 20,034 & $4,547,718$ \\
\hline & State/DIPOA & 5,180 & $1,243,200$ \\
\hline \multirow[t]{2}{*}{ Heart } & Federal (SIF) & 77,428 & 100,656 \\
\hline & State/DIPOA & 64,532 & 85,182 \\
\hline \multirow[t]{2}{*}{ Diaphragm } & Federal (SIF) & 1,989 & 2,386 \\
\hline & State/DIPOA & 473 & 567 \\
\hline \multirow[t]{2}{*}{ Esophagus } & Federal (SIF) & 7,469 & 4,481 \\
\hline & State/DIPOA & 826 & 495 \\
\hline \multirow[t]{2}{*}{ Liver } & Federal (SIF) & 767,686 & $3,608,124$ \\
\hline & State/DIPOA & $1,183,763$ & $5,587,361$ \\
\hline \multirow[t]{2}{*}{ Intestine } & Federal (SIF) & 3,146 & 28,304 \\
\hline & State/DIPOA & 212,908 & $1,914,042$ \\
\hline \multirow[t]{2}{*}{ Tongue } & Federal (SIF) & 51,766 & 67,295 \\
\hline & State/DIPOA & 2,721 & 3,618 \\
\hline \multirow[t]{2}{*}{ Lungs } & Federal (SIF) & 203,973 & 444,661 \\
\hline & StateDIPOA & 259,188 & 565,029 \\
\hline \multirow[t]{2}{*}{ Kidneys } & Federal (SIF) & 45,461 & 36,368 \\
\hline & State/DIPOA & 10,559 & 8,552 \\
\hline
\end{tabular}

*Evaluated period SIF: 2012 to 2015. Evaluated period DIPOA: 2014 to 2018.

Table 4. Amount lost due to bovine slaughter condemnations due to parasitic diseases in establishments under Federal Inspection in Brazil, from 2012 to 2015, in million dollars.

\begin{tabular}{|c|c|c|c|c|c|c|}
\hline \multirow{2}{*}{ Condemnation } & \multicolumn{4}{|c|}{ Year } & \multirow{2}{*}{$\begin{array}{c}\text { Annual } \\
\text { average }\end{array}$} & \multirow{2}{*}{$\begin{array}{c}\text { Loss } \\
\text { simulation* } \\
\text { (adding 23\%)* }\end{array}$} \\
\hline & 2012 & 2013 & 2014 & 2015 & & \\
\hline Cisticercosis & 3.4 & 2.5 & 2.4 & 2.1 & 2.6 & 3.3 \\
\hline Hidatidosis & 0.6 & 0.5 & 0.4 & 0.5 & 0.5 & 0.6 \\
\hline Fasciolosis & 1.1 & 0.9 & 1.0 & 1.1 & 1.0 & 1.3 \\
\hline Total & 5.1 & 4.0 & 3.9 & 3.7 & 4.1 & 5.2 \\
\hline
\end{tabular}

*Considering that the number of injuries followed the same pattern regardless the type of slaughtering house we can simulate adding $23 \%$ (state and municipal slaughtering).

Table 5. Value lost due to bovine slaughter condemnations due to parasitic diseases in establishments under State Inspection in Rio Grande do Sul, from 2014 to 2018, in million dollars.

\begin{tabular}{|c|c|c|c|c|c|c|c|}
\hline \multirow{2}{*}{ Condemnation } & \multicolumn{5}{|c|}{ Year } & \multirow{2}{*}{$\begin{array}{l}\text { Annual } \\
\text { average }\end{array}$} & \multirow{2}{*}{$\begin{array}{l}\text { Loss } \\
\text { simulation* } \\
\text { (adding } \\
51 \%)^{*}\end{array}$} \\
\hline & 2014 & 2015 & 2016 & 2017 & 2018 & & \\
\hline Cisticercosis & 1.1 & 0.6 & 1.1 & 0.9 & 1.7 & 1.1 & 2.2 \\
\hline Hidatidosis & 0.6 & 0.3 & 0.3 & 0.3 & 0.2 & 0.3 & 0.8 \\
\hline Fasciolosis & 1.5 & 1.0 & 1.1 & 1.6 & 1.9 & 1.4 & 2.9 \\
\hline Esofagostomosis & 0.2 & 0.4 & 0.4 & 0.6 & 0.6 & 0.4 & 0.9 \\
\hline Total & 3.5 & 2.5 & 2.9 & 3.5 & 4.5 & 3.2 & 6.8 \\
\hline
\end{tabular}

${ }^{*}$ Considering that the number of injuries followed the same pattern regardless the type of slaughtering house we could simulate adding $39 \%$ under Federal Inspection System and 12\% under Municipal Inspection System (51\%). 


\section{Results}

\section{Data from Federal Inspection Service (SIF) in Brazil}

During the studied period, 97 million bovines were slaughtered nationwide in slaughterhouses under Federal inspection. Among their carcasses, more than 1.2 million parts were condemned only due to parasitic causes during post-mortem inspection (Table 3). There was an average annual loss in SIF establishments of 2.6 million US\$ for cysticercosis, 529 thousand US\$ for hydatidosis, and more than 1 million US\$ due to fasciolosis (Table 4). Although cold treatment of cysticercosis-infected carcasses is the most effective and commonly used method, it costs 23.27 US $\$$ per animal, which also represents a significant economic loss in the production chain (Rossi et al., 2014). If we consider all parasitoses that result in condemnations, we have a total loss of 4.1 millionUS\$ per year (Table 4). The result of the simulation, when considering all inspection spheres, shows a total loss of 5.2 million US\$ (Table 4).

\section{Data from State inspection system in Rio Grande do Sul}

Considering only Rio Grande do Sul state, in its state inspection establishments(DIPOA), where most animals are slaughtered, there were high values of average annual loss, such as 1.1 million US $\$$ for cysticercosis, 391 thousand US\$ for hydatidosis, 458 thousand US\$ for esophagostomosis and the 1.4 million US\$ loss for fasciolosis (Table 5). The simulation shows 6.9millionUS\$ lost total, considering that all cattle slaughtered in the other spheres would have the same condemnation occurrence pattern (Table 5).

\section{Discussion}

Lesion numbers should be analyzed together with the number of slaughtered animals in order to not overestimate or underestimate disease rates. Spatial analysis, through occurrence maps, facilitates data analysis and interpretation. Table 6 shows the number of slaughtered animals per state in the period evaluated in SIF establishments. It is important to emphasize that states of Amapá, Alagoas, Ceará, Federal District, Pernambuco, Piauí, Rio de Janeiro, Rio Grande do Norte and Roraima were not included in the survey since only animals slaughtered under Federal inspection were considered, and in these States, there were no SIF establishment assets during the period studied. These places are likely to have the diseases studied; however, it would be necessary to evaluate the state and municipal inspection services, since they constitute the total slaughtering in these regions. It's also important to know that parasitosis occurrences measured through slaughterhouses do not exclusively reflect local health situation as, sometimes, cattle from one locality are slaughtered in the nearby state, and not in their state of origin.

Table 6. Cattle slaughtered in Brazilian states between 2012 and 2015 under Federal Inspection System (SIF).

\begin{tabular}{cc}
\hline Brazilian State & Number of cattle slaughtered (2012-2015) \\
\hline Mato Grosso & $19,161,088$ \\
Mato Grosso do Sul & $14,482,660$ \\
São Paulo & $11,497,265$ \\
Goiás & $11,338,688$ \\
Minas Gerais & $8,955,119$ \\
Rondônia & $8,237,842$ \\
Pará & $7,211,599$ \\
Tocantins & $4,190,147$ \\
Paraná & $3,951,466$ \\
Rio Grande do Sul & $2,860,143$ \\
Bahia & $1,876,104$ \\
Maranhão & $1,628,181$ \\
Acre & $1,029,364$ \\
Santa Catarina & 401,791 \\
Amazonas & 193,705 \\
Sergipe & 171,414 \\
Espírito Santo & 18,196 \\
Total & $97,204,772$ \\
\hline
\end{tabular}




\section{Cysticercosis}

SIF data shows that, in absolute numbers, the state that had the most animals affected with cysticercosiscompatible lesions was Mato Grosso do Sul, with 103 thousand cases, and was second in number of animals slaughtered. In São Paulo state, there were 71 thousand cases, occupying the second place in number of lesions, and this was the third state in the number of slaughtered animals. Special attention should be given to Rio Grande do Sul's numbers, because even though it was in tenth place for slaughtered animals in SIF establishments, it has had the third largest number of cysticercosis lesions, with 27 thousand cases. In figure 1 this distribution can be observed.

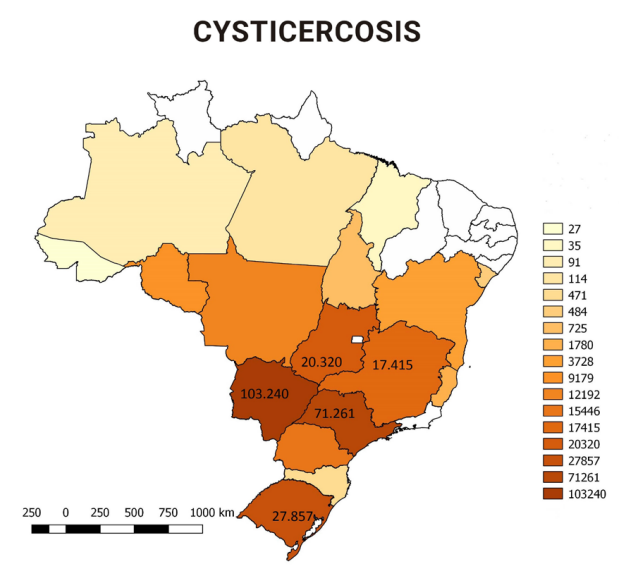

\section{FASCIOLOSIS}

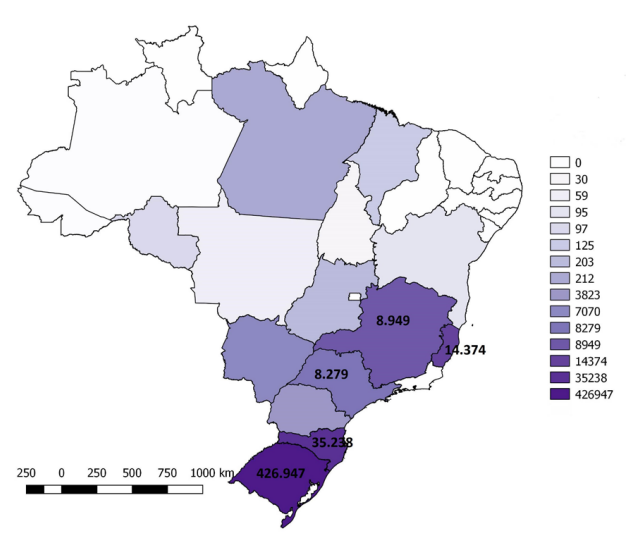

HYDATIDOSIS

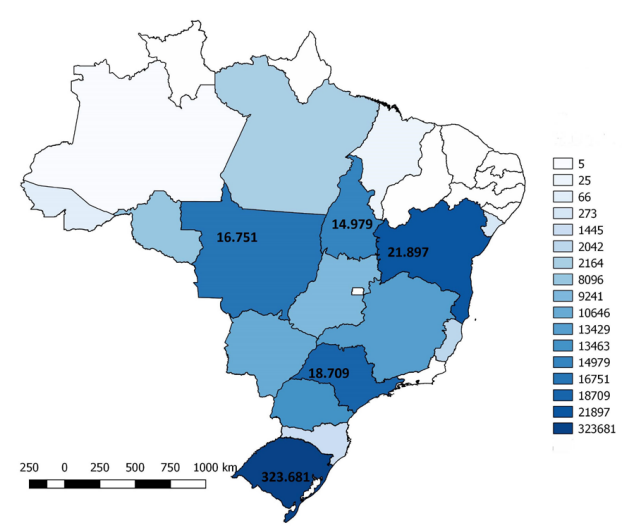

Figure 1. Brazilian Maps showing the number of cysticercosis, fasciolosis and hydatidosis lesions in cattle, by state, between 2012 and 2015, highlighting highest occurrence states. 
Cysticercosis studies in cattle in RS shows a prevalence between 2.5\%, in the recent studies (Teixeira et al., 2015), and $4.6 \%$, in older studies (Corrêa et al., 1997). There is a predominance of extensive breeding, often in small field areas, contributing to greater contact between humans and animals, as well as human excrement through pasture and water courses through an inadequate disposal of sewage in rural areas. In Brazil's Southeastern and Midwest regions there is an increase in cattle confinement systems (Nieto et al., 2012; Felippe et al., 2014). This system limits livestock contact with human waste, and generally corresponds to large areas of business with greater attention to basic sanitation. This is a possible explanation for a relatively higher number of cysticercosis lesions in RS state.

In Rio Grande do Sul state the region that sends most animals with cysticercosis lesions, in absolute numbers, is the southwest region. However, this is the region with the highest number of cattle being sent to slaughter. When analyzing the percentage of animals with cysticercosis lesions destined to slaughter in the state, we have a different result, as can be seen in Figure 2. Regions in the north and northeast were sent the most animals with cysticercosis (in relation to the number of animals sent to slaughter). According to a previous study conducted by Aragão et al. (2010), there are large number of cases in regions with indigenous communities, which was compatible with what found in this research.

The same situation was also observed in mountainous regions of the state. This data corroborates with a study by Nieto et al. (2012), which showed that smaller properties and those closer to urban centers had a higher risk of cysticercosis infection, and animals in dairy farms (main activity in the region) remain longer on the property compared to those on beef cattle properties.

\section{Fasciolosis}

In the present study, SIF losses were around 1 million US\$ over the course of each year from 2012 to 2015. In Rio Grande do Sul analyses (DIPOA DATA), losses were expressive, especially in the years 2017 and 2018 (1.6 and 1.9 million dollars), which can be explained by the rainfall index of previous years. It rained $3.114 \mathrm{~mm}$ in 2015 and $2.141 \mathrm{~mm}$ in 2016, and both values were higher than the average for the state, which was usually close to $1.500 \mathrm{~mm}$ (INMET, 2018). A high rainfall index contributes to maintenance of wetlands even during the summer, contributing directly to the survival of the intermediate host, a snail of genus Lymnaea.

Literature data on carcass weight reductions due to this disease added to losses from discarding livers were considered different from this study, in which only losses due to organ condemnations were recorded. It was also found by the authors that the losses were constant over the years, demonstrating that there has not been adequate control of this parasite, and that in the following years, it is probable that the same number of animals will remain at risk. Data for the whole country shows an extremely higher occurrence of fasciolosis in the southern states, especially RS, which holds $84 \%$ of the Brazilian fasciolosis lesions (Figure 1).

Beck (1993) investigated the presence of Fasciola spp. eggs in cattle feces and also observed highest occurrence rate in the southern states followed by São Paulo, Minas Gerais and Rio de Janeiro, similar to what was found in this research. This zoonosis is frequent in Rio Grande do Sul, as it finds ideal conditions for its proliferation. Besides the temperature, the physiographic condition with flooded areas, the presence of invertebrate hosts and management techniques such as breeding and fattening animals in rice growing areas contributed to the development of this disease in the southern region of Brazil specially in south and southeast of Rio Grande do Sul state (Cunha et al., 2007; Dutra et al., 2010).

When analyzing the map of slaughtered animals in Rio Grande do Sul state inspection establishments that presented lesions of fasciolosis, it can be observed that in absolute numbers the southwest region presents the highest value (Figure 2), showing the same patter observed when evaluating cysticercosis.

The epidemiological survey of this disease in each region is essential for planning an appropriate control. The impact of diseases such as fasciolosis deserves more attention, and the compilation of information on the evolution of occurrences can be used to predict future events, allowing preventive interventions (Molento \& Pritsch, 2018).

\section{Hydatidosis}

Southern Brazil is considered a hyperendemic zone, both for domestic ruminants and for humans. In Rio Grande do Sul, hydatidosis is a serious public health problem, especially in municipalities bordering Uruguay or Argentina, due to the sheep herding in the region. Clandestine slaughter and the access of dogs to hydatic cyst infected viscera is the main reason for the large number of cases of this parasitosis (Tessele et al., 2013). The 


\section{CYSTICERCOSIS}
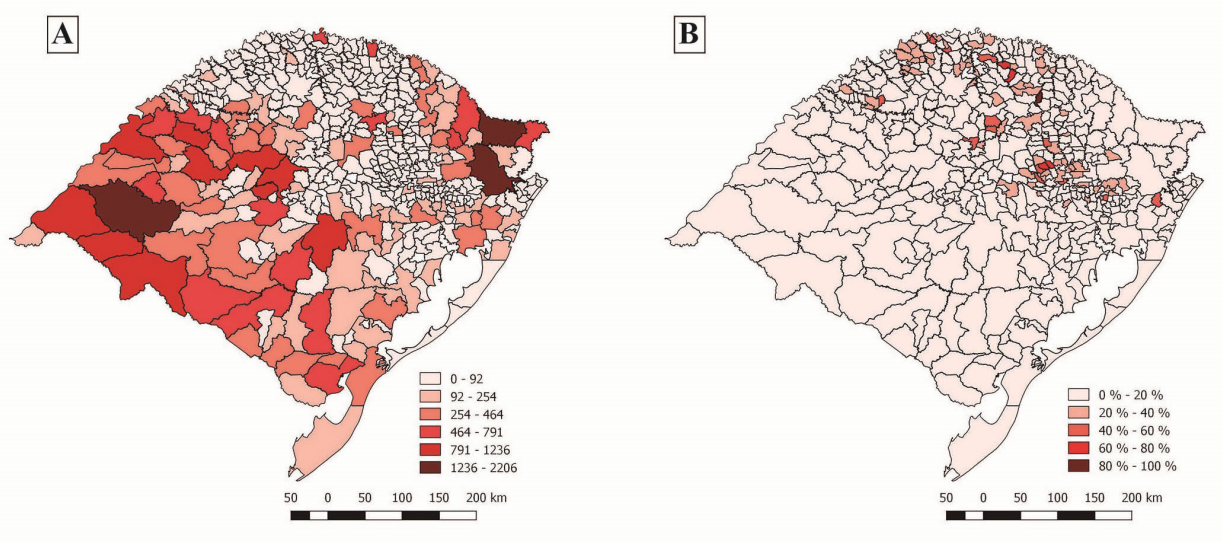

\section{FASCIOLOSIS}
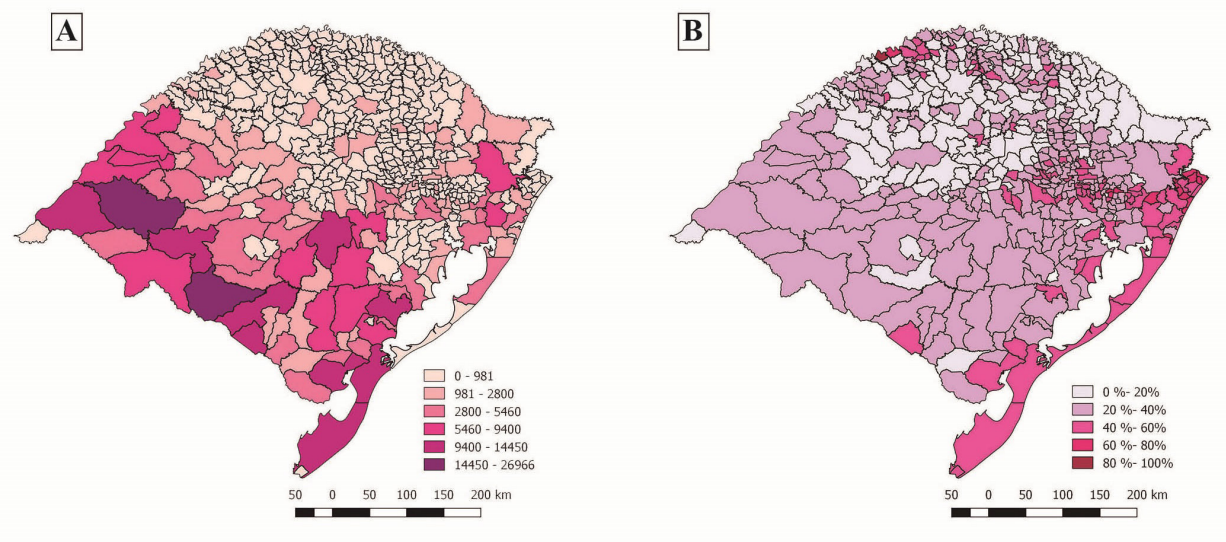

\section{HYDATIDOSIS}
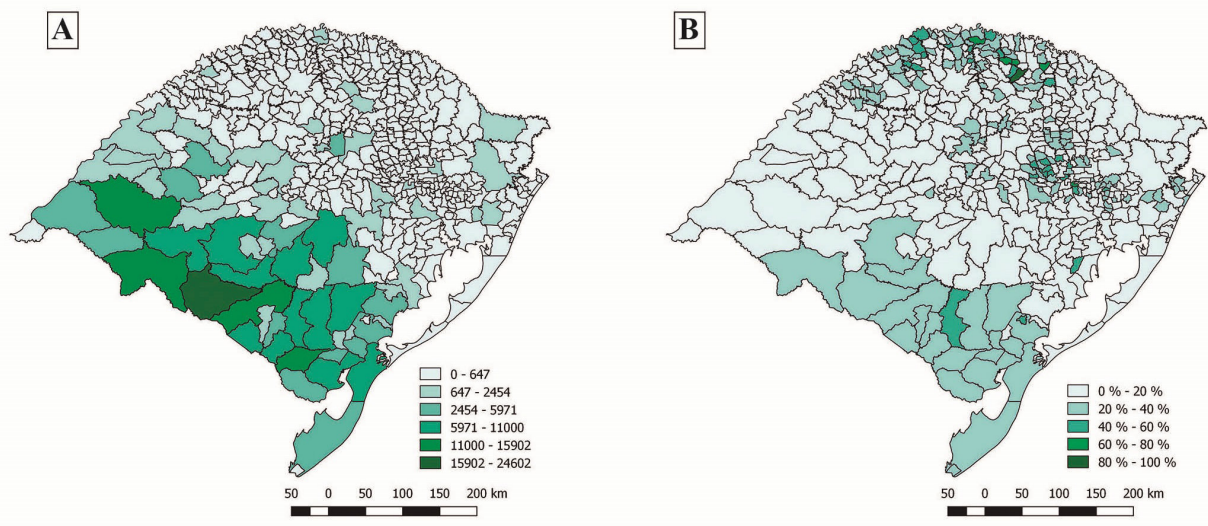

Figure 2. Slaughtered cattle between 2015 and 2018 in establishments under state inspection that presented cysticercosis, fasciolosis and hydatidosis compatible lesions. " $A$ " is the total number of animals that presented lesions. " $B$ " is the percentage of animals that presented lesions in relation to the total sent to slaughter. 
intercropping of cattle with sheep and the use of the dogs in rural work, a common practice in Rio Grande do Sul, contributes to the maintenance in both species, bovine and ovine. Public policies in other countries, such as New Zealand (Lawson, 2010) and Uruguay (Cóppola, 2013), significantly reduced cases of this parasitosis showing that this also must be done in Rio Grande do Sul state for an improvement in animal and public health.

In SIF analysis, Rio Grande do Sul state, despite being in 10th place in the number of bovine slaughtered in establishment sunder Federal Inspection, it represents the state with the highest number of animals affected by hydatidosis, with 323 thousand cases, followed by other states with lower numbers, such as Bahia with 22 thousand cases and São Paulo with 18 thousand cases (Figure 1). When we analysed data only for Rio Grande do Sul state, in DIPOA establishments, it is possible to verify that the highest number of affected animals was in the southern border region (Figure 2), as already analysed by Paz (2004).

\section{Conclusions}

The analysis clearly demonstrated that the economic impact of parasites is extremely high, even though they are controllable through management techniques and sanitary procedures. There is still a lack of data from municipal inspection slaughterhouses, which would make this impact even greater. The information contained in this study emphasizes the importance of food inspection work and shows that investments in this area could bring a return in reducing condemnations, especially in Rio Grande do Sul state.

\section{Acknowledgements}

This study was supported by the Conselho Nacional de Desenvolvimento Científico e Tecnológico (CNPq), Coordenação de Aperfeiçoamento de Pessoal de Nível Superior - Brasil (CAPES). Finance code 001.

\section{References}

Aragão SC, Biondi GF, Lima LGF, Nunes CM. Animal cysticercosis in indigenous Brazilian villages. Rev Bras Parasitol Vet 2010; 19(2): 132-134. http://dx.doi.org/10.1590/S1984-29612010000200014. PMid:20624354.

Beck AAH. Fasciolose. Hora Vet 1993; 13(75): 65-70.

Cabrera PA, Lloyd S, Haran G, Pineyro L, Parietti S, Gemmell MA, et al. Control of Echinococcus granulosus in Uruguay: evaluation of different treatment intervals for dogs. Vet Parasitol 2002; 4(104): 333-340. http://dx.doi.org/10.1016/S0304-4017(01)00603-3. PMid:11777612.

Cóppola B. Hidatidosis: debemos tenerla presente. Rev Plan Agropec 2013; 175: 42-44.

Corrêa GLB, Adams NA, Angnes FA, Grigoletto SF. Prevalência de cisticercose em bovinos abatidos em Santo Antônio das Missões, RS, Brasil. Rev FZVA 1997; 4(1): 77-80.

Cunha FOV, Marques SMT, Mattos MJT. Prevalence of slaughter and liver condemnation due to Fasciola hepatica among sheep in the state of Rio Grande do Sul, Brazil 2000 and 2005. Parasitol Latinoam 2007; 62(3-4): 188-191. http://dx.doi.org/10.4067/ S0717-77122007000200015.

Dijkhuizen AA, Morris RS. Animal Health Economics: principles and applications. Sydney: University of Sydney; 1997.

Dutra LH, Girotto A, Vieira RFC, Vieira TSWJ, Zangirolamo AF, Marquês FAC, et al. The prevalence and spatial epidemiology of cysticercosis in slaughtered cattle from Brazil. Semina: Ciênc Agrár 2012; 33(5): 1887-1896. http://dx.doi.org/10.5433/16790359.2012v33n5p1887.

Dutra LH, Molento MB, Naumann CR, Biondo AW, Fortes FS, Savio D, et al. Mapping risk of bovine fasciolosis in the south of Brazil using Geographic Information Systems. Vet Parasito/ 2010; 169(1-2): 76-81. http://dx.doi.org/10.1016/j.vetpar.2009.12.015. PMid:20071083.

Felippe AG, Pinto PSA, Santos TO, Nieto ECA, Peixoto RPMG, Silva LF. Características favoráveis ao controle do complexo teníasecisticercose em uma região rural de Minas Gerais, Brasil. Rev Bras Cienc Vet 2014; 21(4): 243-246. http://dx.doi.org/10.4322/ rbcv.2015.303.

Food and Agriculture Organization - FAO. Livestock primary data. Epi Info [online]. Rome: FAO; 2016 [cited 2018 July 18]. Available from: http://www.fao.org/faostat/en/\#data/QL

Instituto Nacional de Meteorologia - INMET. Consulta a gráficos de parâmetros por período. [online]. 2018 [cited 2018 Dec 30]. Available from: http://www.inmet.gov.br/portal/index.php?r=tempo/graficos 
Investing.com. Epi Info [online]. 2019 [cited 2018 Dec 31]. Available from: https://br.investing.com/

Kale MC, Aral Y, Aydin E, Cevger Y, Sakarya E, Güloglu SC. Determination of By-Product Economic Values for Slaughtered Cattle and Sheep. Kafkas Univ Vet Fak Derg 2008; 17(4): 551-556. http://dx.doi.org/10.9775/kvfd.2010.3945.

Lawson JR. Hydatid disease and sheep measles: the history of their control and the economics of a recent change of control policy. N ZJ Zool 2010; 21(1): 83-89. http://dx.doi.org/10.1080/03014223.1994.9517978.

Marques GM, Buzi KA, Galindo LA, Baldini ED, Biondi GF. Avaliação dos registros de condenação por cisticercose em bovinos abatidos em frigoríficos da região centro oeste do estado de São Paulo, 1996 a 2000. Vet Zootec 2008; 15(1): 114-120.

Molento MB, Pritsch IC. Fasciola hepatica em bovinos no Brasil: uma doença negligenciada [online]. 2018 [cited 2018 Oct 1]. Available from: http://www.agroin.com.br/noticias/11960/fasciola-hepatica-em-bovinos-no-brasil-uma-doenca-negligenciada

Nieto ECA, Ferreira PS, Santos TO, Peixoto RPMG, Silva LF, Felippe AGG, et al. Prevalência do complexo teníase-cisticercose na zona rural de Matias Barbosa-MG. Semina: Ciênc Agrár 2012; 33(6): 2307-2314. http://dx.doi.org/10.5433/1679-0359.2012v33n6p2307.

Nif AN, Alonge DO. An economic surveys of abattoir data in Fako division of south west province, Cameroon (1978-1980). Bull Anim Health Prod 1987; 35(3): 239-242.

Paz FAZ. Situação da hidatidose no Rio Grande do Sul. Proyecto sub regional conosur de control y vigilancia de lahidatidosis in Argentina, Brasil, Chile y Uruguay [online]. 2004 [cited 2018 Dec 10]. Available from: https://bibliotecavirtualfacias.files.wordpress. com/2016/05/equinoc.pdf

QGIS Trademark. Get started using QGIS [online]. 2018 [cited 2019 Jan 24]. Available from: https://www.qgis.org/en/site/forusers/ index.html\#download

Rossi GAM, Grisolio APR, Prata LF, Burger KP, Hoppe EGL. Situação da cisticercose bovina no Brasil. Semina: Ciênc Agrár 2014; 35(2): 927-938. http://dx.doi.org/10.5433/1679-0359.2014v35n2p927.

Teixeira JLR, Recuero ALC, Brod CS. Estudo Ambispectivo de coorte da cisticercose bovina em abatedouros com serviço de inspeção municipal (SIM) na região sul do Rio Grande do Sul, Brasil. Rev Patol Trop 2015; 44(2): 146-154. http://dx.doi.org/10.5216/ rpt.v44i2.36644.

Tessele B, Brum JS, Barros CSL. Lesões parasitárias encontradas em bovinos abatidos para consumo humano. Pesq Vet Bras 2013; 33(7): 873-889. http://dx.doi.org/10.1590/S0100-736X2013000700008. 